\title{
The problem of development of entrepreneurship and entrepreneurial education in Russia
}

\author{
Alexander S. Semenov ${ }^{1, *}$ and Ekaterina A. Eremeeva ${ }^{2}$ \\ ${ }^{1}$ Moscow Technological Institute, 199334, Moscow, Russia \\ ${ }^{2}$ Higher School of Economics, Department of Finance, 101000, Moscow, Russia
}

\begin{abstract}
Now in Russia the innovative model of development is implemented, so new instruments of innovative project financing are required. Hence, the necessary competences should be formed within the educational system. To study the influence of different factors on venture capital and entrepreneurial activity, the work considers the analysis of the different research papers, which study the determinants of the venture capital development. According to the results of testing, the possible hypotheses are outlined and verified. The analysis was performed on two datasets, which represent the annual data for Russia and the USA from 1994 to 2012. As the influence factors on the VC industry the model uses determinants both used in previous works and completely new. The latter are the level of small business development, the inventors' activity coefficient, and the level of information and communications industry development in a country. As a dependent variable, the total volume of venture investments, transformed into logarithmic scale is used. The result of the paper shows the primary factors of VC and technological entrepreneurship development, which also influence on the demand for entrepreneurial education.
\end{abstract}

\section{Introduction}

The actuality of the research issue is determined by the increasing role of the entrepreneurial education as the global trend in the most countries with the developed and developing economies.

International practice shows the time-proved techniques of teaching entrepreneurship: it is recommended to teach the foundations of entrepreneurship, entrepreneurial spirit, fundamentals of marketing and finances, strategies of manufacture construction and the management of company growth.

Strategic approach to the entrepreneurial education in leading univesities implies great amount of practice, aimed at the entrepreneurial competences development (such as the estimation of possibilities to start a business, net-working, strategy development, risk estimation and decreasing). All courses are developed with the integration of practical elements into the curricula. The focus is made on the experimental education and business-planning and pitch-competitions are integrated into the courses.

Nowadays entrepreneurial education in Russia is not at all a developed field. Departments of management and entrepreneurship in many higher educational institutions teach 'about entrepreneurship', rather than entrepreneurship itself. That does not develop competences and entrepreneurial spirit in students. As such a discipline did not exist 10 years ago, there is still the deficit of specialists and methods of education.
According to the poll of 2013 within the framework of the project Global Competitiveness Report, 79\% of the operating entrepreneurs consider the development and implementation of the special entrepreneurial programs in the education activity of Russian institutions of higher and vocational education as the primary issue. Besides, 23\% respondents were sure that entrepreneurial education and business-skills teaching are the important factors of the entrepreneurship development in Russia [1].

It demands attention, that according to all-Russian Public Opinion Research Center 23\% of Russian citizens have a strong desire for business setup. Such desire is typical for the residents of towns (32\%) and young people, aged between 18 and 24 (46\%) [2].

But this desire faces the low level of entrepreneurs' competence in the field of small business and startup management, which causes the low rate of Russian companies' survivability. According to GEM (Global Entrepreneurship Monitoring), only 33\% can survive the edge of 3.5 years of active operation (for instance: in the countries of Western Europe and USA such indicator is never lower 50\%) [3].

The problem can be solved at the level of initiatives of entrepreneurs' associations, and not on the state level only. The mechanism of venture entrepreneurship is insufficiently developed in our country yet. The most important reason of this is the lack of the clear methodology of the national venture management model and the strategy of state participation in its development.

Corresponding author: semenov.venture@mail.ru 
It is necessary to improve methodological approaches to the creation of the efficient model of venture entrepreneurship development. In this case the key task is the detection of macro-economic factors and the factors of innovation development of the national economy, which have the significant influence on the Russian market of venture capital development.

Although the foreign studies contain different factors, influencing the increase of venture investments efficiency in detail, the direct transfer of experience to the Russian market is incorrect, due to the significant institutional and infrastructure differences. Thus, despite the great number of theoretical works, revealing the problems of venture business efficiency estimation, there is the lack of practical research, which can offer the complex approach to the search of ways of increasing the market of venture capital activity in Russia.

\section{The research overview dedicated to the development of venture capital}

There exist a significant number of foreign researchers who deal with determinant analysis of venture capital [4-7].

The dynamic effect of GDP growth over the venture capital is assessed through a line forecasting model described in works by [8-10] and quarterly figures of the USA market in 1995-2011. The model assessment leads to results correlated with theoretical foundation that the economics growth has a positive affect on venture investments. The same results are achieved in other researches across the USA and OECD countries [11, 12]. However, work [13] has got statistical unimportance of this determinant, which is explained as a strong correlation with the IPO's market share in GDP rather than overall growth.

The inflation rate discourages investors to make long-term investments as a result of depreciation [14]. These factors were proved in $[10,15]$ works. The authors of work [10], during the empirical research, have uncovered a significant inflation impact on venture investment volume. However, the late stages of target companies have a positive effect on venture investments. The authors link this phenomenon with investor's desire to bring the companies to IPO with the aim of reducing potential losses resulted by inflation.

According to economic theories, interest rates effect the volume of investments [16, 17]. This theory was proved in studies by the work [15], the authors of which research the influence of real interest rates on venture investments volume. But the opposite result was obtained in the works $[11,12]$, using short-term interest rates in the research. According to the authors, the growth of the short-term interest rates leads to the increase of venture capital attractiveness for the leaders of innovation companies, if compared to the bank crediting.

The role of financial market in the development of venture capital market is determined on the basis of stock market depth indicator. This index is the relation of the general cost of shares, sold at the stock market of a country to the average volume of the GDP of this country [18]. Results of the empiric study, including this determinant support the positive significant influence of the stock market depth on the venture investments $[15,18]$.

To analyze the nature of the entrepreneurial environment influence on the venture market activity, many researchers consider such proxy-variable as the index of labor market rigidity $[12,15,18]$. High level of labor market rigidity has negative effect on the state of entrepreneurial environment, which in its turn has negative effect on the venture investors' activity.

It should be mentioned that nowadays there are no published results of the fundamental research of the dynamic of venture investment in innovative projects of Russian companies, using the modern methods of empiric analysis. The greater part of the existing publications, concerning the problems of Russian venture market, has rather descriptive, non-empiric character.

\section{Empirical analysis. Determinant of venture industry development level}

\subsection{Methodology of empirical research}

As a basic model, the Autoregressive Distributed Lags Model, ADL [19], with error correction model, ECM, was applied.

The general view of ADL-model can be designated as $\operatorname{ADL}(p, q, n)$, where $p-$ is a number of Lags $Y_{t}, q-$ is a number of Lags $X_{t}, n-$ is a number of exogenous variables and write down the following equation:

$$
Y_{t}=\alpha_{0}+\sum_{i=1}^{p} \alpha_{i} Y_{t-i}+\sum_{j=1}^{n} \sum_{i=0}^{q} \beta_{j p} X_{j t-i}+v_{t}
$$

where $Y_{t}-$ is dependable variable, $X_{t}-$ independent variables, $v_{t}-$ white noise process.

By applying the Lag Operator L: $L Y_{t}=Y_{t-1}, L X_{t}=X_{t-1}$, with ADL-model, we can get the following equation:

$$
Y_{t}=\alpha_{0}+\left(\sum_{i=1}^{p} \alpha_{i} L^{i}\right) Y_{t}+\sum_{j=1}^{n}\left(\sum_{i=0}^{q} \beta_{j p} L^{j}\right) X_{j t}+v_{t}
$$

Coefficients $\beta j$ are impulse multipliers and their sum is an indicator of factor influence on dependant variable in a long-term perspective (long-term multiplier). In models which feature logarithmic values, the impulses are called flexibilities standing for percentage growth of function value at $1 \%$ growth of factor value.

While combining within the short/long-term dynamics the ADL-model can be presented as an error correction model, ECM:

$\Delta Y_{t}=\sum_{i=1}^{p-1} \alpha_{i} \Delta Y_{t-i}+\sum_{j=1}^{n} \sum_{i=0}^{q-1} \beta_{j p} \Delta X_{j t-i}-\gamma\left(Y_{t-1}-\alpha_{L}-\sum_{j=1}^{n} \beta_{L} X_{j t-1}\right)+v_{t}$

Bracketed expression in the right stands for declination of dependable variable from long-term balance at previous point of time. Thus, short-term change of dependable variable can be identified by two summands: instantaneous response to short-term change 
of dependable variables $\left(\alpha_{L}\right)$ and correction of declination of long-term balance at a previous point of time $\left(\beta_{L}\right)$. The negative sign at the second testifies the return of $Y_{t}$ to the long-term balance. The rest part of equation specifies short-term correlation between dependent variable and regressors.

\subsection{Description of data and variables}

For conducting this analysis the two selections were applied. These are annual data of Russia and USA for 1994 to 2012. The start of selection is conditioned by appearance of statistic information in regard to venture deals in Russia, published in analytical reviews of the Russian Association of Private Equity and Venture Investments (RAVI). All data were nominated in US millions of dollars. When forming time series, the analytical RAVI reviews, the database of the Department of Economic Analysis of the USA (DEA), Organization of Economic Cooperation and Development (OECD), World Bank (WB), the World Trade Organization (WTO), Small Business Association of the USA (SBA), the World Intellectual Property Organization (WIPO), National Venture Capital Association of the USA (NVCA) were used as reporting data.

As a dependent variable, the indicator of total venture investments is used transformed into logarithmic $(\operatorname{LnVC})$. To study its influence on current indicator of total venture investments, this model was added by Lagged value of this indicator $(\operatorname{LnVC}(\mathrm{t}-\mathrm{k}), \mathrm{k}=1, \mathrm{n})$. This is conditioned by investments made in several stages, therefore funds invested in period $(\mathrm{t}-1)$ can effect the investments activity in period $t$.

With the purpose of deep study of venture industry development it can be interesting apart from using standard determinants to apply additional set of determinants never tested by anyone before. The level of investors' activity, market share, ICT sector services development, as well as the level of small business development are made the key indicators.

The business costs for $R \& D$ is a reflection to conditions created by the state to attract private funding for high technological branches of economics. The increase of these costs raises demand for venture investments of innovative companies. For the assessment of influence of this factor over the venture capital, the model was added by LnNiokr variable, calculated as a logarithm of inner expenditures by organizations for scientific research and developments.

The high security level of intellectual property is a necessary condition for successful commercialization of new technologies. Invent variable is used as the indicator of the level of inventor's activity, calculated as the number of patent applications per 10 thousand people.

Informatization and outsourcing as the form of business management is wide-spread now. Using of outsourcing by the businesses enables to reduce the expenses, concentrating on the most profitable activities. The sector of information and communication technologies plays the key role in the process of such services rendering. Thus, the development of ICT sector provides the competitiveness of the national economy and, as a result, influences its investment attractiveness. The variable $I K T$ is used as the indicator of the level of ICT development, which is determined as the share of goods and services of the ICT sector in the total volume of country's export.

Small business is the active participant of the innovation process due to its mobility and high receptivity to innovations. Small businesses highly demand financial support at the initial stage of operation. They receive support due to the venture investments into the capital. Small innovation businesses are divided into the internal venture, attracting the finances of the private investors for projects realization and the external venture, using the money of pension funds, insurance companies, public capital. Thus, we should study the relation of small entrepreneurship and the venture capital.

The level of small business development characterizes the number of the operating small enterprises and the amount of employees, engaged in small business and is reflected in $\operatorname{LnMP}$ variable.

Thus, the dependence of the venture capital volume on the above mentioned determinants can be presented in the following way:

$$
\begin{gathered}
\text { LnVC }=f\left(\text { LnVC }_{t-k}, \text { GDPgr, Inflat, Capcr, LnNiokr },\right. \\
\text { Invent, IKT, LnMP, LnLabour })
\end{gathered}
$$

$L n V C$ - Volume of venture investments, GDPgr - Rate of GDP growth, Inflat - Rate of inflation, Capcr - Financial market structure, LnNiokr - R\&D expenses, Invent Coefficient of inventive activity, IKT - Level of ICT development, LnMP - Number of small businesses, LnLabour - Number of employees, engaged in small business.

\subsection{Empirical testing of the determinants of the level of venture capital development}

Regressive analysis in this study was conducted with the use of econometric E-views package.

Results of Dickey-Fuller and Phillips-Perron test on the unit root show the nonstationarity of the initial time series of Russian and the USA. To transform them into the stationary ones, the method of the first order differences of the row values was used. Thus, the initial rows are integrated of the first-order and they can have co-integration tie, enabling to construct short-term and long-term prognoses of the variables dynamics and interrelations between them.

Further analysis of data on Russia determined the existence of the significant (5\% level of significance) correlation between the variables D (LnLabour) and $\mathrm{D}$ (LnMP), $\mathrm{D}$ (LnLabour) and $\mathrm{D}(\mathrm{IKT})$, as well as $\mathrm{D}$ (LnLabour) and $\mathrm{D}$ (Inflat). That is why variable $\mathrm{D}$ (LnLabour) will be excluded from the further regressive analysis for Russia. As a result of the similar analysis, the further specification of the model for the USA does not contain the variable D(LnMP).

The model for Russia, constructed and estimated by the OLS method, looks the following way: 


$$
\begin{gathered}
\text { DLnVC }=-0.074+0.205 \cdot \operatorname{DLnVC}(-2)+4.130 \\
\cdot \text { DLnMP }(-2)+0.925 \cdot \operatorname{DLnNiokr}(-3)+0.379 \cdot \\
\text { DInvent }+0,241 \cdot \text { DIKT }+0,318 \cdot \operatorname{DIKT}(-1)+ \\
0.119 \cdot \text { DCapcr(}(-1)+-0.463 \cdot \operatorname{DInflat}(-1)+ \\
0.811 \text { DGDPgr }
\end{gathered}
$$

\section{For the USA:}

$\mathrm{DLnVC}=-0.246+0.821 \cdot \operatorname{DLnVC}(-1)+$

$11.318 \cdot$ DLnNiokr $+3.152 \cdot$ DLnNiokr $(-2)+$

$0.215 \cdot$ DInvent $(-2)-0,202 \cdot \operatorname{DInflat}(-2)+$

$1,857 \cdot \operatorname{DGDPgr}+5.915 \cdot \operatorname{DGDPgr}(-2)+0,279$

$$
\cdot \text { DIKT }+0,117 \cdot \operatorname{DIKT}(-1)+6,063 \text {. }
$$

DLnLabour(-2)

These models are stable and well-specified.

The obtained results prove that the greater contribution to the increase of the volume of venture capital market in Russia is made by the number of small enterprises in the country. Besides, the effect of this value is realized with delay: the increase of the number of small enterprises by $1 \%$ leads to the growth of venture investments by $4.1 \%$ in two years. This fact conforms to the role of small entrepreneurship in the innovation development of the economy, because the implementation of new technologies occurs with the participation of small business. As it was mentioned above, venture capital is the key tool of innovation projects financing.

There is the common situation with the inner expenses of companies on R\&D: when their volume increases by $1 \%$, the volume of the venture investments increases by $0.9 \%$ in three years. The lag of these values can be determined by the time period, which is necessary for the innovation companies to get the first results of a new product development and its demonstration to the investors.

The rate of GDP increase significantly influences on the dependent variable, while the positive effect of this factor influence occurs in the course of the considered period. It can be explained by the close dependence of the rate of economic growth on the investors' activity. When the rate of GDP growth increases by $1 \%$, the volume of venture investments increases by $0.8 \%$.

The inventive activity, the level of ICT sector development and the lag structure of venture investments also influence the dynamics of Russian market of venture capital in short-term period. The increase of the inventive activity by $1 \%$ in the current year leads to the increase of the venture capital market by $0.4 \%$. The indicator of ICT sector development influences less, but its effect can be seen within two years: the current year a little bit less than the previous one $(0.2 \%$ and $0.3 \%$ correspondingly). This situation can be explained from the position that the growth of the national economy competitiveness (one of its indicators is ICT sector) attracts the foreign investors as well.

Of all the considered variables, the indicator of the financial market structure has the least positive impact on the volume of venture investments in Russia in shortterm period. The increase of this indicator by $1 \%$, the increase of venture investments is only $0.1 \%$. This fact reveals the real picture, because the domestic fund market still lacks the conditions, attractive for the venture investors. But, may be, the foundation of the new institution of development will improve this situation.

And, finally the obvious negative significant influence of inflation on the volume of venture capital is obtained.

Dynamics of the market of venture capital in the USA is caused by the organizations' expenditures on R\&D to a large extent, but this impact in the current period is four times more, than two years before. The increase of the of the American companies' R\&D expenditures by $1 \%$ leads to the increase of the volume of venture investments by $11.3 \%$ and $3.2 \%$, correspondingly. The significant contribution to the volume of venture capital in the short-term period is made by the small entrepreneurship, as well as in Russia. The increase of the number of employees, engaged in small business by $1 \%$ leads to the increase of venture investments by $6 \%$ in two years.

The rate of GDP growth and its lag structure $(1.9 \%$ and $5.9 \%$, correspondingly) is the third among the considered indicators according to the level of positive effect on the venture market, as well as in Russia.

The inventive activity and the level of ICT sector development have less essential, but also significant impact on the volume of the US venture capital market ( $0.2 \%$ and $0.3 \%$, correspondingly). The increase of the current value of the ICT level makes twice more contribution, if compared to the values of the previous year. The influence of the lag structure of the volume of venture investments and the rate of inflation on the current value of the dependent variable is similar to the data, obtained for Russia.

Despite Russia, the indicator of the financial market structure in model for the USA is insignificant, which is probably concerned with the insufficient duration of the initial time series.

Thus, we can make the conclusion that the small entrepreneurship development and the organizations' expenditures on R\&D are the major drivers of venture investments growth in the short-time period both in Russia and the USA. Besides, the invention activity of the population and the development of ICT sector, being the significant factors, have less impact on the venture market development.

\section{Conclusion}

We believe that the main reason why entrepreneurial development in Russia is losing out to those of American and other developed countries is primarily a poor development innovative venture entrepreneurship.

In order to catch up with developed countries, a study of venture industry determinants on USA and Russia model was conducted.

The novelty of conducted study lies in using determinants in economic analysis and their influence on venture investments have not been studied before by other authors. These determinants are the level of development of small business, public invention 
activities ratio and the level of ICT-industry development in the country.

The econometrical analysis revealed the following results: regressive analysis of short-term interactions between researched variables has shown a dominant influence on the total venture investments in both Russia and USA.

The increase by $1 \%$ of small businesses in Russia and people engaged in USA's small businesses results the growth of total venture markets by $4,1 \%$ and by $6 \%$ respectively. This fact correlates with the small businesses' role in innovative economic development as the new technologies are mostly applied with participation of small businesses and the key financial instrument for innovative projects investments is venture capital.

Venture costs by companies encourage venture investments. The increase by $1 \%$ results in the growth of Russia's venture investments by $0,9 \%$ and by $11,3 \%$ in the USA. Thus, it proves the fact that R\&D expenses by businesses is the reflection of conditions created by the state to attract private investments for high technological industries of economics. The increase of expenses raises demand for venture investments of innovative companies.

Determinates like GDP growth, the level of ICTsector development, invention activity ratio also make a positive effect on total venture investments, however their contribution to venture markets increase is less compared to aforesaid determinants.

The determinants' indicators of financial markets have turned out to be ambiguous. This is an important indicator for Russia, but its influence on dependable variable has a rather minor effect. By $1 \%$ increase the growth of venture investments in Russia makes up only $0,1 \%$. As for the USA this variable has revealed an insignificant coefficient what could be a result of improper duration of temporary rows.

The reported study was supported by RFBR, research project No. 14-06-00446 a

\section{References}

1. Amway Global Entrepreneurship Report 2013. Available: https://assets1.bywebtrain.com/501522/ 2013_amway_global_entrepreneurship_report_1.pdf ?r $=1 \overline{9} 20$

2. Press Release No. 2314 "Your Own Business: Pro and Contra" (2013) Available: http://old2.wciom.ru/index.php?id=268\&uid=11418 0

3. O.R. Verhovskaya, M.V. Dorohina, A.V. Sergeeva, National Report "Global Monitoring of
Entrepreneurship. Russia (2013) Available: http://www.gsom.spbu.ru/images/cms/data/faculty/g em_2013_final20_all.pdf

4. A. P. Groh, J. Wallmeroth, Determinants of Venture Capital Investments in Emerging Markets, Social Science Researching Network (2015) URL: http://ssrn.com/abstract=2605452

5. D. S. Hain, S. Johan, D. Wang, Journal of Business Ethics, 1-22 (2015)

6. Cumming, Douglas, S. Johan, M. Zhang, Corporate Governance: An International Review, 22, 162-178 (2014)

7. N. Rajarishi, S. Hazarika, K. Tandon, 49, 1039-1070 (2014)

8. O. Jordà, The American Economic Review, 95, 161$182(2005)$

9. O. Jordà, The Review of Economics and Statistics, 91, 629-647 (2009)

10. D. Stimel, Economics and Finance Review, 2, 3845 (2012)

11. P.A. Gompers, J. Lerner, What drives Venture Capital Fundraising? Brookings Papers on Economic Activity. Microeconomics, 149-192 (1998)

12. A. Romain, B. Pottelsberghe, The Determinants of Venture Capital: A Panel Data Analysis of 16 OECD Countries, IIR Working Paper WP, 3-2 (2003)

13. L.A. Jeng, Ph.C. Wells, Journal of Corporate Finance, 6, 241-289 (2000)

14. N.G. Mankiw, Principles of Economics, (SouthWestern College Pub., 2003)

15. S. Bonini, S. Alkan, The Political and Legal Determinants of Venture Capital Investments around the World, (2011) URL: http://ssrn.com/abstract $=945312$

16. G. Khaberler Prosperity and Depression. Theoretical Analysis of Cyclical Fluctuations, (Chelyabinsk; Sotcium, 2008)

17. P. A. Samuelson, W. D. Nordhaus, Economics, (Mcgraw-Hill Higher Education, 2009)

18. Q.A. Yafengyun, Survey of Venture Capital in Europe. Implications for the Chinese Venture Capital Market (Juridiske fakultet. Universitetet i Oslo, 2010)

19. G.G. Kantorovich, HSE Economic Journal: electronic scientific journal, 6, 498-523 (2002) URL:

http://ecsocman.hse.ru/hsedata/2010/12/31/1208182 146/06_04_06.pdf

20. I.V. Robert, Modern information technologies in education: didactic problems; prospects of application (1994) 